\title{
Towards Capability Maturity Model of e-Learning Process
}

\author{
Yong Zhou \\ Software Engineering Institute, East China Normal University, Shanghai, China \\ Email: yzhou@sei.ecnu.edu.cn
}

Received April 12, 2012; revised May 27, 2012; accepted June 10, 2012

\begin{abstract}
ePCMM (e-Learning Process Capability Maturity Model) is used for evaluating the capability and maturity of an institution engaged in e-Learning based on e-Learning key process areas. It is a stepwise process improvement which can be implemented by both staged model and continues model.
\end{abstract}

Keywords: e-Learning; Evaluation; ePCMM

\section{Introduction}

The e-Learning Maturity Model (eMM) model was developed in New Zealand by Marshall [1]. The method is based on gathering evidence about 5 processes categories in the e-Learning lifecycles and takes a holistic view of maturity, addressing multiple aspects. See five eMM process categories in Table 1.

Between 6 and 11 processes activities are identified as key indicators of the process area. Marshall indicated 10 key indicators in learning process, 6 in development process, 11 in co-ordination process, 7 in evaluation process and 9 in organization process [2]. While 5 dimensions (levels) of process capability were defined, each key indicator in different process area can cover at least 1 or multi dimensions. See dimensions of process capability in Table 2.

The performance of each key indicator in different levels (Not adequate, Partially adequate, Largely adequate, Fully adequate) demonstrates the capability of the institution that running e-Learning business (for detail about eMM, please refer to Marshall's paper [1,2]).

In current eMM, each process key indicator is marked in different color to demonstrate the performance of each dimension, it is easy to show, but hard to metric the effectiveness of the process improvement, also it is hard to use auto evaluation tools. Thus, a quantitative model is proposed to metric the capability and maturity for an educational institution that running e-Learning business, that is e-Learning Process Capability Maturity Model (ePCMM).

\section{2. еРСMM}

In this paper, we propose an e-Learning process capability maturity model based on eMM.

\subsection{Metric e-Learning Process}

It is necessary to have quantitative approach to metric the capability and maturity for an educational institution that running e-Learning business [3].

In order to metric each key indicator, we set $v_{i}(i=\{1$, $2,3,4,5\})$, as the value of each key indicator of the process in different dimensions, according to their performance, let $v_{i}=\{0,2,4,6\}$, (0 refers to Not adequate, 2 refers to Partially adequate, 4 refers to Largely adequate, 6 refers to Fully adequate). Computing the weighted average on $v_{i}(i=\{1,2,3,4,5\})$, we get value $a$, $a$ refers to the metric of general performance of a specific key indicator. See Equation (1) as below.

$$
a=\sum_{i=1}^{5} w_{i} * v_{i} ; \quad \sum_{i=1}^{5} w_{i}=1\left(0 \leq w_{i} \leq 1\right)
$$

$w_{i}$ refers to the weight of each dimension for a specific key indicator, for easy reference, we suggest equal effect on each dimension of the key indicator, therefore, the weight of each dimension is the same, in above case:

$$
w_{i}=0.2(i=\{1,2,3,4,5\})
$$

In Marshall's learning process [1], there are 10 key indicators, each is valued by weighted average on 5 dimensions (from dimension 1 to dimension 5). If each dimension is fully adequate for all key indicators of learning process, then every key indicator is valued in same: $a=$ 6 , therefore, the metric of learning process in above case is: $a^{*} 10=60$. Similarly, we can get metrics of all five process areas of eMM.

\section{2. ePCMM Meta Model}

Next, a process meta-model of our proposed e-Learning capability maturity model is setup. See Figure $\mathbf{1}$.

In Figure 1, each process category defined in eMM is 
Table 1. eMM process categories [2].

\begin{tabular}{ll}
\hline Process category & Brief description \\
\hline Learning & $\begin{array}{l}\text { Processes that directly impact on pedagogical } \\
\text { aspects of e-Learning }\end{array}$ \\
Development & $\begin{array}{l}\text { Processes surrounding the creation and } \\
\text { maintenance of e-Learning resources }\end{array}$ \\
Co-ordination & $\begin{array}{l}\text { Processes surrounding the oversight and } \\
\text { management of e-Learning }\end{array}$ \\
Evaluation & $\begin{array}{l}\text { Processes surrounding the evaluation and } \\
\text { quality control of e-Learning through its } \\
\text { entire lifecycle }\end{array}$ \\
Organization & $\begin{array}{l}\text { Processes associated with institutional } \\
\text { planning and management }\end{array}$ \\
\hline
\end{tabular}

Table 2. Dimensions of process capability.

\begin{tabular}{|c|c|}
\hline Dimension (level) & Focus \\
\hline 5: Optimizing & $\begin{array}{l}\text { Continual improvement in all aspects } \\
\text { of the e-Learning process }\end{array}$ \\
\hline 4: Managed & $\begin{array}{l}\text { Ensuring the quality of both the } \\
\text { e-Learning resources and delivery }\end{array}$ \\
\hline 3: Defined & $\begin{array}{l}\text { Defined process for development and } \\
\text { support of e-Learning }\end{array}$ \\
\hline 2: Planed & $\begin{array}{l}\text { Clear and measurable objectives for } \\
\text { e-Learning projects }\end{array}$ \\
\hline 1: Deliverable & $\begin{array}{l}\text { Performing e-Learning process and } \\
\text { making delivery }\end{array}$ \\
\hline
\end{tabular}

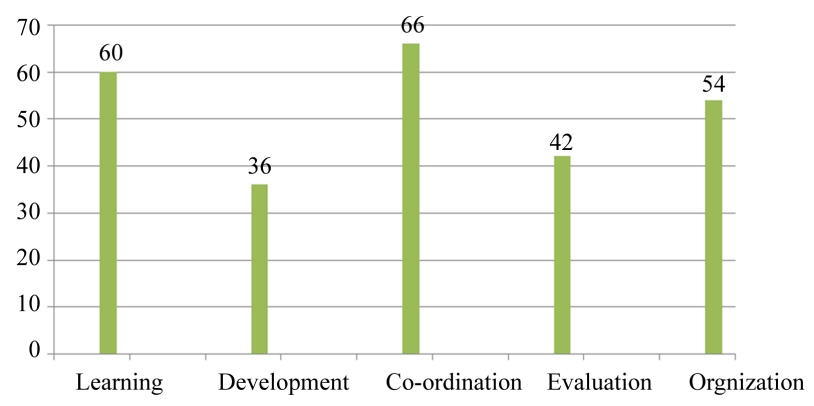

Figure 1. ePCMM process meta-model.

valued according to above mentioned key indicator metric equation (the key indicators are chosen as per Marshall's model [1]), the process meta-model shows full value on each process area.

\subsection{Staged Model of ePCMM}

The staged model of ePCMM is defined in 6 maturity levels (ML). See Table 3.

The staged model of ePCMM provides a roadmap to organizational process improvement. Each stage of maturity level covers every e-Learning process area, with value of all related key indicators, using key indicator metric Equation (1).

The e-Learning process maturity level of the organization grows up step by step, see the satisfied condition of each stage of maturity level in Table 4 . The staged model of ePCMM has two advantages:
Table 3. Staged model of ePCMM.

\begin{tabular}{ll}
\hline Maturity level & Description \\
\hline 5: Optimizing & $\begin{array}{l}\text { Keep improving on all aspect of e-Learning } \\
\text { process }\end{array}$ \\
4: Managed & $\begin{array}{l}\text { Quality assurance on e-Learning resource and } \\
\text { delivery }\end{array}$ \\
3: Defined & $\begin{array}{l}\text { Define process for e-Learning development } \\
\text { and support }\end{array}$ \\
2: Planed & $\begin{array}{l}\text { Have a clear and quantitative goal on } \\
\text { e-Learning program }\end{array}$ \\
1: Deliverable & Set up e-Learning process and make delivery \\
0: Initial & Ad hoc \\
\hline
\end{tabular}

Table 4. Satisfied condition of each stage.

\begin{tabular}{cl}
\hline ML & Satisfied condition \\
\hline 0 & $\begin{array}{l}\text { Ad hoc } \\
1\end{array}$ \\
$\begin{array}{l}\text { Value of each indicators on dimension } 1 \text { in all process } \\
\text { areas is no less than } 4\end{array}$ \\
2 & $\begin{array}{l}\text { When ML1 is satisfied, value of each indicators on } \\
\text { dimension } 2 \text { in all process areas is no less than } 4\end{array}$ \\
3 & $\begin{array}{l}\text { When ML2 is satisfied, value of each indicators on } \\
\text { dimension } 3 \text { in all process areas is no less than } 4\end{array}$ \\
4 & $\begin{array}{l}\text { When ML3 is satisfied, value of each indicators on } \\
\text { dimension } 4 \text { in all process areas is no less than } 4\end{array}$ \\
5 & $\begin{array}{l}\text { When ML4 is satisfied, value of each indicators on } \\
\text { dimension } 5 \text { in all process areas is no less than } 4\end{array}$ \\
\hline
\end{tabular}

1) The staged model provides a stepwise process platform that support e-Learning process improvement for the organization. The organization should fix the problems in each dimension of all e-Learning process areas at a certain level in order to step on a higher level.

2) The staged model defines e-Learning process maturity level for the organization, it is easy for cross organization comparing.

However, the staged model of ePCMM also has two disadvantages:

1) In order to achieve a certain maturity level, the organization must fulfill performance in all process areas at the level as well as its' bellowing levels. It is less flexibility.

2) A lot of process improvements need to do concurrently at each dimension, that lead to higher effort and cost.

\subsection{Continuous Model of ePCMM}

The continuous model is defined various distribution of capability level (CL) on any one of e-Learning process area. It is defined in 6 capability levels (CL). See Table 5.

Unlike staged model which should cover all process areas, the continuous model allows the user to choose preferred process areas to perform. As in staged model, each process area is valued by related key indicators according to key indicator metric Equation (1). For the 
Table 5. Continuous model of ePCMM.

\begin{tabular}{ll}
\hline Capability level & Description \\
\hline 5: Optimizing & $\begin{array}{l}\text { Has capability of keeping improvement on all aspect } \\
\text { of e-Learning process }\end{array}$ \\
4: Managed & $\begin{array}{l}\text { Has capability of quality assurance on e-Learning } \\
\text { resource and delivery }\end{array}$ \\
3: Defined & $\begin{array}{l}\text { Has capability of defining process for e-Learning } \\
\text { development and support }\end{array}$ \\
2: Planed & $\begin{array}{l}\text { Has capability of making a clear and quantitative } \\
\text { goal on e-Learning program }\end{array}$ \\
1: Performed & $\begin{array}{l}\text { Has capability of performing e-Learning process and } \\
\text { making delivery }\end{array}$ \\
0: Incomplete & $\begin{array}{l}\text { Has no capability of performing any of e-Learning } \\
\text { process }\end{array}$ \\
\hline
\end{tabular}

organization, there are different capability levels in different process areas.

The continuous model is an add-on model, it is not allowed to skip over at any levels. See the satisfied condition of each capability level (CL) in Table 6.

The continuous model has two advantages:

1) The continuous model provides flexibility for user to improve process. It allows user to decided priority of process improvement activities according to the business goal.

2) The organization can compare capability in the same process at different times to evaluate its' e-Learning process progress. With continuous model, user can define different capability levels in different process areas, it is easy to identify the strengths and weakness in process improvement.

The continuous model of ePCMM also has two disadvantages:

1) Since there is no defined process order in continuous model, it needs specialist to conduct process improvement, in order to decided which process areas need to be improved and what is the priority of improvement activities.

2) Although the organization making process improvement with continuous model, it is difficult to make organizational comparing to process capability.

\subsection{Maturity vs Capability}

Comparing with staged model and continuous model (Figure 2), it presents different view of ePCMM.

The staged model can be implemented to make cross organization comparing with maturity, while the continuous model can be implemented to compare capability in the same process at different times for the organization itself.

\section{Conclusions}

This paper proposed a e-Learning process capability maturity model (ePCMM) which focuses on process management, it evaluates the capability maturity level of an
Table 6. Satisfied condition of each CL.

\begin{tabular}{|c|c|}
\hline CL & Satisfied condition \\
\hline 0 & Ad hoc \\
\hline 1 & $\begin{array}{l}\text { Value of each indicators on dimension } 1 \text { in specific } \\
\text { process area is no less than } 4\end{array}$ \\
\hline 2 & $\begin{array}{l}\text { When CL1 is satisfied, value of each indicators on } \\
\text { dimension } 2 \text { in specific process area is no less than } 4\end{array}$ \\
\hline 3 & $\begin{array}{l}\text { When CL2 is satisfied, value of each indicators on } \\
\text { dimension } 3 \text { in specific process area is no less than } 4\end{array}$ \\
\hline 4 & $\begin{array}{l}\text { When CL3 is satisfied, value of each indicators on } \\
\text { dimension } 4 \text { in specific process area is no less than } 4\end{array}$ \\
\hline 5 & $\begin{array}{l}\text { When CL4 is satisfied, value of each indicators on } \\
\text { dimension } 5 \text { in specific process area is no less than } 4\end{array}$ \\
\hline
\end{tabular}

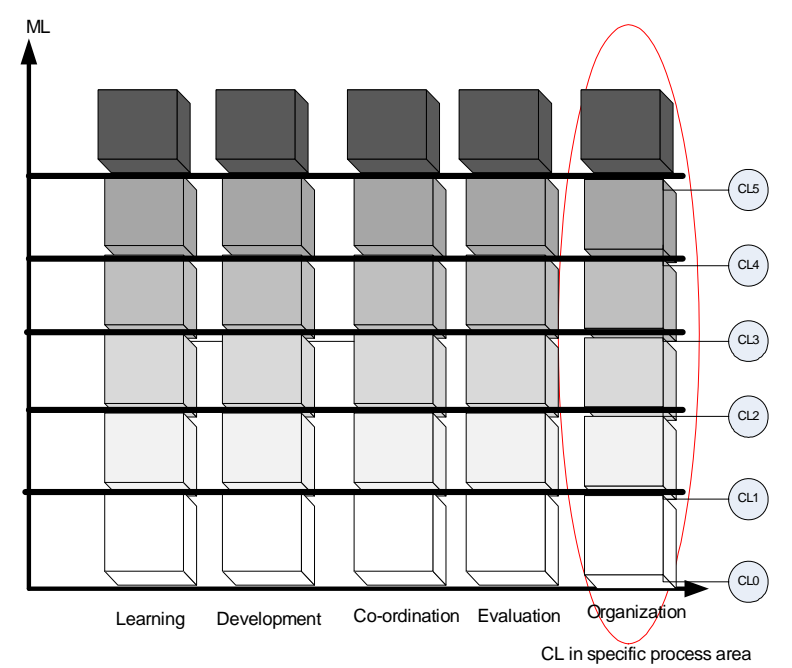

Figure 2. Maturity vs capability.

organization that running e-Learning program.

To be different from the educational or technical approach to make an assessment of e-Learning, this model emphasis on whether the e-Learning organization has the capability of delivering a high quality and persistent service of e-Learning.

The ePCMM is based on CMM/CMMI [4], which achieves a great success in software engineering. Since the challenge facing institutions developing e-Learning is similar to that which faces organizations engaged in software development, to introduce this software process management evaluation framework into e-Learning field is feasible and realistic.

In our future work, more process data from various educational institution that running e-Learning program need to be collected and analyzed, to determine considerable weight in above mentioned equation to compute value $a$. while how to use ePCMM effectively is still need to discuss.

\section{REFERENCES}

[1] S. Marshall and G. Mitchell, “An e-Learning Maturity 
Model," Proceedings of the 19th Annual Conference of the Australian Society for Computers in Learning in Tertiary Education, Auckland, 8-11 December 2002.

[2] S. J. Marshall and G. Mitchell, "Applying SPICE to eLearning: An e-Learning Maturity Model,” Proceedings of the Sixth Australasian Computing Education Conference (ACE2004), Dunedin, 18-22 January 2004.
[3] Y. Zhou and J. P. Zhang, "A Quantitative Approach to eMM,” Proceedings of ICWL, Shanghai, 20-22 August 2008, pp. 69-72.

[4] Software Engineering Institute, "CMMISM for Systems Engineering and Software Engineering (CMMI-SE/SW, V1.1)," 2002. 